\title{
Morphometric differences between urothelial cells in voided urine of patients with grade I and grade II bladder tumours
}

\author{
MATHILDE E BOON, PHJ KURVER, JPA BAAK, ECM OOMS* \\ From the Stichting Samenwerking Delftse Ziekenhuizen, Department of Pathology, Reynier de Graefweg 7, \\ Delft, and *Vrije Universiteit, Department of Pathology, De Boelelaan 1117, Amsterdam, The Netherlands
}

SUMMARY The morphometric differences between the urothelial cells in the voided urine of $24 \dot{\omega}$ patients with grade I and grade II bladder tumours were measured. In both wet-fixed Papanicolaoustained smears as in air-dried Giemsa-stained preparations, the cells in the grade I tumours are $\stackrel{\rho}{\rightarrow}$ larger and have more pronounced anisocytosis and a smaller nucleus to cytoplasm area $(\mathrm{N} / \mathrm{C})_{0}^{\mathrm{N}}$

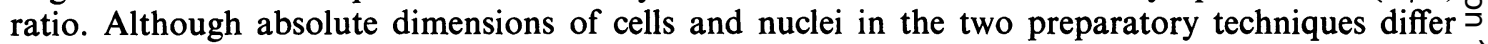
significantly, the average $\mathrm{N} / \mathrm{C}$ ratios are similar. In both methods almost all grade $\mathrm{I}$ tumours have $\vec{c}$ average $\mathrm{N} / \mathrm{C}$ cell size ratios of less than 0.6 and grade II tumours more than $0 \cdot 6$. Morphometrically urothelial cells could not be distinguished from cells exfoliated from grade I bladder tumours. The results indicate that it is feasible to classify bladder tumours using the morphometric values of the $\stackrel{\oplus}{\oplus}$ exfoliated urothelial cells alone.

Grade I bladder tumours do not shed identifiable tumour cells and so cannot usually be diagnosed cytologically. On the other hand, a significant proportion of the grade II tumour can be detected cytologically ${ }^{1}$ because the exfoliated cells can be recognised as malignant. The neoplastic cells from grade II tumourscan be identified as cancer cells because of certain quantitative features. For example, recent studies have shown that a large proportion of cells in grade II tumours have a raised DNA content. ${ }^{2}$ It is difficult, however, to translate the findings from DNA studies into the microscopical images with which the cytopathologist is confronted in his diagnostic work. On the other hand, the results from morphometry can be easily assimilated by the histopathologist. $^{34}$ Therefore we carried out morphometry measurements on urothelial cells in voided urine of cases with grade I and grade II bladder tumours to discover the most distinctive and objective diagnostic criteria, and to compare the cell features in the wet-fix Papanicolaou method with those in the air-dried Giemsa method.

\section{Material and methods}

CYTOLOGY AND HISTOLOGY

Voided urine was used for this study. Two con-

Accepted for publication 12 November 1980 secutive samples were taken from each patient and the smears with the highest cytological grading were used. In eight patients with grade I tumours and $17 \stackrel{\circ}{\mathrm{D}}$ with grade II tumours, both the air-dried Giemsa- $\stackrel{\varrho}{\Rightarrow}$ stained smear and the wet-fixed Papanicolaou- $\bar{O}$ stained smear were used; in another case of grade II tumour, only the air-dried Giemsa-stained preparation was available for study. Samples made from bladder scraping of 25 patients without urological용 complaints were used as control smears.

The wet-fixation was achieved by spray-fixing (coating fixative $80 \mathrm{ml}$ polyethyleneglycol (MW 300), 8 $690 \mathrm{ml}$ isopropanol, $170 \mathrm{ml}$ acetone, $60 \mathrm{ml}$ distilled water). The smears for the Giemsa method were 을 air-dried before staining. The histological sections of $D$ the bladder tumours were classified according to the WHO classification. ${ }^{5}$ There were six borderline cases, which were classified by six pathologists indepen- or dently: when the mean score was $1 \cdot 0-1 \cdot 5$, the case $N$ was classified as a grade I tumour, and when the mean score was $1 \cdot 6-2 \cdot 0$, as a grade II tumour.

\section{MOR PHOMETRY}

In each smear, 50 urothelial cells were measured. $\stackrel{\oplus}{\oplus}$ Except for the exclusion of cells with degenerative 0 features, cells were selected at random. The measure- $\overrightarrow{0}$ ments were performed with a graphic tablet (ASM, $\stackrel{\mathbb{D}}{\stackrel{Q}{Q}}$ Leitz, West Germany) equipped with a camera $\stackrel{\oplus}{\mathbb{D}}$ lucida system. The cursor could be seen through the $\frac{\Omega}{\sigma}$ 
camera lucida drawing tube, and the contour of the nuclei and cells outlined. The computer calculated the following features from the two delineated areas: nuclear perimeter, cell perimeter, nuclear area, cell area, nuclear size $\left(2 \sqrt{\frac{\text { area }}{\pi}}\right)$, cell size, nucleus to cytoplasm area $(\mathrm{N} / \mathrm{C})$ ratio, N/C size ratio. From each slide the mean and the standard deviation of the assessed features was calculated. This gave 16 sets of values per case.

\section{STATISTICAL ANALYSIS}

Statistical analysis was carried out on a PDP11 computer DEC with a part of the program STP (statistical package) developed by one of us (PHJK). The descriptive statistics of the measurements in the air-dried Giemsa-stained and the wet-fixed Papanicolaou-stained smears were computed for the two groups. Wilcoxon's test was used to establish the significance of differences between the two groups. A level of significance of $p<0.05$ was adopted.

\section{Results}

WET-FIXED PAPANICOLAOU-STAINED SMEARS The morphometric parameters show many differences between the two tumour groups (Table 1). Significant differences were established for the nine sets of values: mean cell perimeter, standard deviation cell perimeter, mean cell area, standard deviation cell area, mean cell size, standard deviation cell size, mean N/C area ratio, mean N/C size ratio and standard deviation $\mathrm{N} / \mathrm{C}$ size ratio. All the cases were plotted in a scattergram with the mean N/C size ratio on the $\mathrm{x}$-coordinate and the mean nuclear area on the y-coordinate (Fig. 1).

Fourteen of the 16 grade II cases, and one of the 8 grade I cases had N/C size ratios of over $0 \cdot 60$. There

Table 1 Descriptive statistics: wet-fixed Papanicolaoustained cells in cases of grade I and grade II tumours

\begin{tabular}{|c|c|c|c|}
\hline \multirow[t]{2}{*}{ Parameters (mean) } & \multicolumn{2}{|c|}{$\operatorname{Mean}(\mu m) \pm S D$} & \multirow{2}{*}{$\begin{array}{l}\text { * Probability of } \\
\text { difference } \\
\text { (two-sided) }\end{array}$} \\
\hline & Grade I & Grade II & \\
\hline $\begin{array}{l}\text { Nuclear perimeter } \\
\text { Cell perimeter } \\
\text { Nuclear area } \\
\text { Cell area } \\
\dagger \text { Nuclear size } \\
\text { Cell size } \\
\text { N/C area ratio } \\
\text { N/C size ratio }\end{array}$ & $\begin{array}{c}31 \cdot 8 \pm 6 \cdot 46 \\
63 \cdot 2 \pm 19 \cdot 7 \\
56 \cdot 8 \pm 23 \cdot 0 \\
223 \pm 154 \\
8 \cdot 3 \pm 1 \cdot 65 \\
15 \cdot 8 \pm 4 \cdot 80 \\
0.32 \pm 0 \cdot 12 \\
0 \cdot 55 \pm 0 \cdot 11\end{array}$ & $\begin{array}{l}31 \cdot 1 \pm 5 \cdot 85 \\
52 \cdot 0 \pm 12 \cdot 1 \\
53 \cdot 3 \pm 21 \cdot 2 \\
138 \pm 62 \\
8 \cdot 01 \pm 1 \cdot 46 \\
12 \cdot 8 \pm 2 \cdot 67 \\
0 \cdot 40 \pm 0 \cdot 10 \\
0.63 \pm 0 \cdot 08\end{array}$ & $\begin{array}{l}0.69(0.10) \\
* 0.0001 *(0.01) \\
0.60(0.15) \\
* 0.0003 *(0.01) \\
0.56(0.08) \\
* 0.0002 *(0.02) \\
* 0.001(0.50) \\
* 0.0003 *(0.02)\end{array}$ \\
\hline
\end{tabular}

*Wilcoxon's test. The asterisks indicate probabilities $<0.05$ in differing from grade I tumours.

$\dagger$ Nuclear size $=2 \sqrt{\frac{\overline{\text { area }}}{\pi}}$.

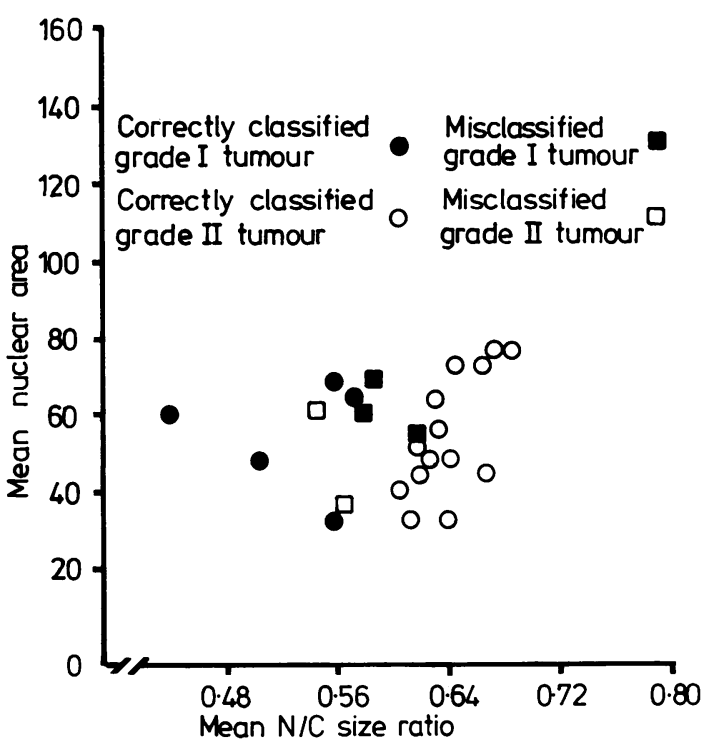

Fig. 1 Scattergram of the mean $N / C$ size ratios and mean nuclear areas of the wet-fixed Papanicolaou-stained urothelial cells. Each symbol represents one case.

was considerable overlap between the grade I tumours and normal urothelium (Table 2). Significant differences were established only for the standard deviations of nuclear size and perimeter.

Table 2 Descriptive statistics of normal urothelial cells prepared with the Papanicolaou and with the Giemsa method

\begin{tabular}{|c|c|c|}
\hline \multirow[t]{2}{*}{ Parameters (mean) } & \multicolumn{2}{|c|}{$\operatorname{Mean}(\mu m) \pm S D$} \\
\hline & Papanicolaou & Giemsa \\
\hline $\begin{array}{l}\text { Nuclear perimeter } \\
\text { Cell perimeter } \\
\text { Nuclear area } \\
\text { Cell area } \\
\text { †Nuclear size } \\
\text { †Cell size } \\
\text { N/C area ratio } \\
\text { N/C size ratio }\end{array}$ & $\begin{array}{c}36 \cdot 2 \pm 5 \cdot 9 \\
80 \cdot 1 \pm 19 \cdot 0 \\
71 \cdot 5 \pm 25 \cdot 1 \\
337 \cdot 7 \pm 177 \cdot 0 \\
9 \cdot 2 \pm 1 \cdot 5 \\
18 \cdot 8 \pm 4 \cdot 5 \\
0 \cdot 29 \pm 0.07 * \\
0 \cdot 53 \pm 0.07 *\end{array}$ & $\begin{array}{c}41 \cdot 9 \pm 5 \cdot 8^{*} \\
88 \cdot 9 \pm 19 \cdot 2 \\
100 \cdot 0 \pm 27 \cdot 5 \\
415 \cdot 3 \pm 153.7 \\
10.8 \pm 1.4^{*} \\
21 \cdot 6 \pm 3.9 \\
0.28 \pm 0.08 \\
0.53 \pm 0.08\end{array}$ \\
\hline
\end{tabular}

*Wilcoxon's test. The asterisks indicate probabilities $<0.05$ in dif fering from grade $I$ tumours.

†Size was computed as follows: Nuclear size $=2 \sqrt{\frac{\text { area }}{\pi}}$.

\section{AIR-DRIED GIEMSA-STAINED SMEARS}

Table 3 shows that in the Giemsa-stained cells, six sets of values proved to be significantly different: mean cell perimeter, mean cell area, standard deviation cell area, mean cell size, mean $\mathrm{N} / \mathrm{C}$ area ratio and mean $\mathrm{N} / \mathrm{C}$ size ratio. The cases plotted in the scattergram (Fig. 2) display that all cases of grade 
II tumours have mean N/C size ratios of over 0.59 , and, in addition, two of the grade I cases. Also in this method there was considerable overlap between normal urothelium and grade I tumours (Table 2). Significant differences were established for only the standard deviations of the $\mathrm{N} / \mathrm{C}$ ratios.

Table 3 Descriptive statistics: air-dried Giemsa-stained cells in cases of grade I and grade II tumours

\begin{tabular}{|c|c|c|c|}
\hline \multirow[t]{2}{*}{ Parameters (mean) } & \multicolumn{2}{|c|}{$\operatorname{Mean}(\mu m) \pm S D$} & \multirow{2}{*}{$\begin{array}{l}\text { * Probability of } \\
\text { difference } \\
\text { (two-sided) }\end{array}$} \\
\hline & Grade I & Grade II & \\
\hline $\begin{array}{l}\text { Nuclear perimeter } \\
\text { Cell perimeter } \\
\text { Nuclear area } \\
\text { Cell area } \\
\text { †Nuclear size } \\
\text { †Cell size } \\
\text { N/C area ratio } \\
\text { N/C size ratio }\end{array}$ & $\begin{array}{l}40 \cdot 3 \pm 7 \cdot 69 \\
81 \cdot 2 \pm 21 \cdot 3 \\
88 \cdot 2 \pm 32 \cdot 9 \\
363 \pm 208 \\
10 \cdot 3 \pm 1 \cdot 94 \\
20 \cdot 3 \pm 5 \cdot 65 \\
0 \cdot 31 \pm 0 \cdot 12 \\
0 \cdot 54 \pm 0 \cdot 11\end{array}$ & $\begin{array}{l}39 \cdot 2 \pm 7 \cdot 56 \\
64 \cdot 1 \pm 16 \cdot 9 \\
89 \cdot 2 \pm 36 \cdot 0 \\
229 \pm 122 \\
10 \cdot 3 \pm 1 \cdot 95 \\
16 \cdot 1 \pm 3 \cdot 96 \\
0 \cdot 34 \pm 0 \cdot 12 \\
0.66 \pm 0.09\end{array}$ & $\begin{array}{c}0.67(0.77) \\
* 0.02(0.16) \\
0.92(0.72) \\
* 0.03 *(0.04) \\
0.97(0.72) \\
* 0.03(0.05) \\
* 0.00(0.62) \\
* 0.00(0.41)\end{array}$ \\
\hline
\end{tabular}

*Wilcoxon's test. The asterisks indicate probabilities $<0.05$ in differing from grade $I$ tumours.

$\dagger$ Nuclear size $=2 \sqrt{\frac{\text { area }}{\pi}}$.

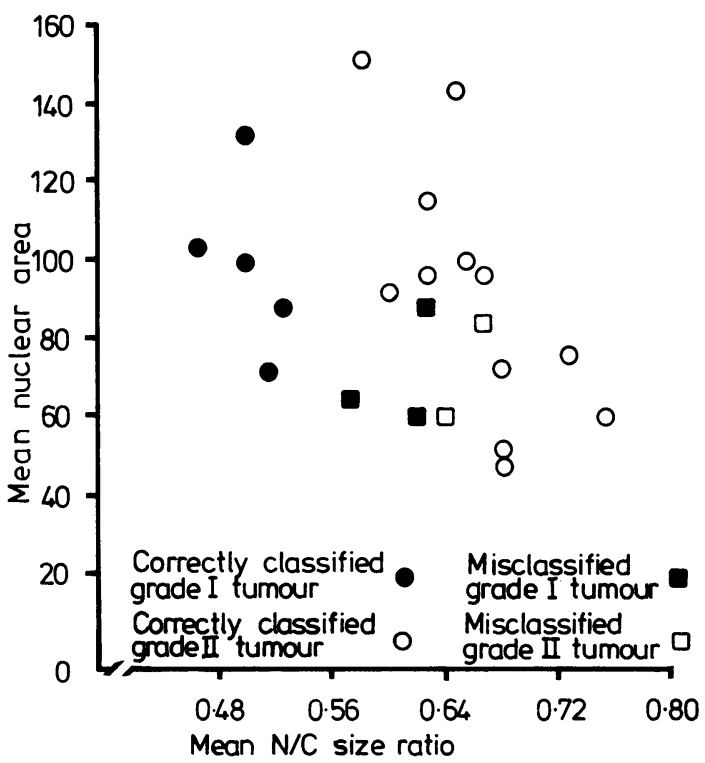

Fig. 2 Scattergram of the mean $N / C$ size ratios and mean nuclear areas of the air-dried Giemsa-stained urothelial cells. Each symbol represents one case.

\section{Discussion}

The results of this investigation show that the cellular and nuclear dimensions of the urothelial cells in the voided urine of patients with grade I and grade II tumours differ, and that normal urothelia cells cannot be distinguished from cells exfoliated from grade I tumours. In routine diagnosis the nuclear and cellular dimensions are used as diagnostic criteria, and therefore the results of this studyo can be of value in the investigation of future cases.0

In both the air-dried Giemsa and the wet-fixedes Papanicolaou methods the best discriminative factor was the N/C ratio. The N/C ratio has proved to bet of major importance in distinguishing other benign ${ }^{\text {s }}$ and malignant lesions $\mathbf{s}^{3} \mathbf{6}$ and as a major indicator in $\vec{\rho}$ the survival of T-I bladder tumours. ${ }^{7}$ In other $\overrightarrow{\vec{\omega}}$ quantitative studies of cells from bladder tumourso the $\mathrm{N} / \mathrm{C}$ ratio as such was not calculated but only then nuclear $\operatorname{size}^{8}{ }^{9}$ which in our study proved to have now value as an indicator (Table 1 and Table 3 ). $A^{+}$ higher N/C ratio was also found in Kern's study ${ }^{10}$ ing the grade II tumours. In his study the mean nuclear area was larger in the grade Il tumours, althougho only grade II tumour cases were measured. Moreover, "characteristic" cells were selected, in contrast to our study in which urothelial cells were measurect at random. The outcome of the two studies are thus not fully comparable. Flow cytometry also allow $\$$ assessment of the relative nuclear size, ${ }^{11}$ and there fore can be applied in the non-selective measurementso of N/C ratios in grade I and II tumours. The resultss of such studies are highly suitable for comparison with our results.

To summarise, therefore, we can say that wher compared with grade II, the $\mathrm{N} / \mathrm{C}$ ratio of grade tumour cells is smaller and while the nuclear dimen- $\frac{1}{3}$ sions are not important, the cell dimensions are. In grade I tumours, cells are invariably larger an $\bar{E}$ associated with a pronounced anisocytosis.

Interesting comparisons can be made between the wet-fixed Papanicolaou-stained smears and the air-dried Giemsa-stained smears. As expected, both the cell and the nuclear areas are larger in the Giemsa method, in which the cells flatten out in the drying process. This is thought to be due to the extreme pressures exerted on cellular structures by thep surface tension of evaporating water, thereby causing collapse of the cells. ${ }^{12}$ This phenomenon was seen in the normal urothelial cells, as well as in the neo* plastic ones.

The application of morphometry also allows thew grading of the parent tumour in individual cases? Using mean $\mathrm{N} / \mathrm{C}$ size ratio as a single discriminating factor, three of the 24 cases were misclassified usingD the Papanicoloau-stained smear, and four other ${ }^{?}$ cases using the Giemsa smear.

These results are highly encouraging, considering we are dealing with a morphological continuum of bladder tumours which have been subjectively classi $\frac{\mathbb{2}}{2}$ fied. We hope to develop a classification rule for the 
(computer-aided) grading of individual bladder tumours in our laboratory, similar to that which we already use for the distinction between endometrial hyperplasia and carcinoma in histological sections ${ }^{4}$ and between follicular adenoma and carcinoma of the thyroid ${ }^{6}$ on cytological material.

We gratefully acknowledge Janneke $\mathrm{v}$ Tilburg, Gerry Streef, Trees Tielemans and Marian Brandhorst for their skilful assistance.

\section{References}

${ }^{1}$ Esposti PL, Zajicek J. Grading of transitional cell neoplasms of the urinary bladder from smears of bladder washings. A critical review of 326 tumors. Acta Cytol 1972;16:529-36

2 Boon ME. DNA content of normal and neoplastic urothelial cells. Tumori $1980 ; 66: 37-49$.

${ }^{3}$ Boon ME, Baak JPA, Kurver PH, Overdiep SH, Verdonk GW. Adenocarcinoma in situ of the cervix: an underdiagnosed lesion. Cancer 1980; (in press).

- Baak JPA, Kurver PHJ, Overdiep SH, et al. Quantitative microscopical (computer-aided) diagnosis of endometrial hyperplasia or carcinoma in individual patients. Histopathology 1980; (in press).

${ }^{5}$ World Health Organization. Histological typing of urinary bladder tumours. International histological classification of tumours. Geneva, 1973.
- Boon ME, Löwhagen T, Lopes Cardozo P, Blonk DI, Kurver PJH, Baak JPA. Computation of pre-operative diagnosis probability for follicular adenoma and carcinoma of the thyroid on aspiration smears. Analytical and Quantitative Cytology 1980; (in press).

' Ooms ECM, Essed E, Veldhuizen RW, Alons CL, Kurver $P$, Boon ME. The prognostic significance of morphometry in T-I bladder tumors. Histopathology 1980;4805.

${ }^{8}$ Fossa SD, Kaalhus $O$. Nuclear size and chromatin in transitional cell carcinoma of the urinary bladder. Beitraege zur Pathologie 1976;157:109-25.

- Levi PE, Cooper EH, Phil D, Anderson CK, Path MC, Williams RE. Analysis of DNA content, nuclear size and cell proliferation of transitional cell carcinoma in man. Cancer 1969;23:1074-85.

10 Kern WH. The cytology of transitional cell carcinoma of the urinary bladder. Acta Cytol 1975;19:420-8.

11 Collste LG, Devonec M, Darzynkiewicz Z, et al. Bladder cancer by flow cytometry. Cancer 1980;45:2389-94.

12 Beyer-Boon ME, Voorn-den Hollander MJA, Arentz PW, Cornelisse CJ, Schaberg A, Fox CH. Effect of various cytopreparatory techniques on normal urothelial cells and their nuclei. Acta Pathol Microbiol Scand [A] 1979; 87:63-9.

Requests for reprints to: Dr Mathilde E Boon, Stichting Samenwerking Delftse Ziekenhuizen, Department of Pathology, Reynier de Graefweg 7, 2625 AD, Delft, The Netherlands. 